\title{
Occupational Therapy in the bereavement process: A meta-synthesis
}

\author{
Daniel Ferreira Dahdah, MSc \\ Ph D Student at the Post-Graduate Programme of Occupational Therapy, Federal University of São Carlos, Brazil. \\ ORCID: 0000-0002-0777-2674
}

\author{
Regina Helena Vitale Torkomian Joaquim, Ph D \\ Associate professor, Department of Occupational Therapy, Federal University of São Carlos, Brazil. \\ ORCID: 0000-0003-3700-397X
}

Introduction: Bereavement is a complex process characterised by a state of grief and suffering, which impacts the health and well-being of the bereaved, and extends to their occupational performance. Thus, occupation can be understood to be central in the expression of bereavement after the death of a loved one as it mediates identity formation, interpersonal relationships, a sense of belonging, and future perspectives.

Purpose: To review English and Portuguese literature and identify how occupational therapists perceive and/or intervene in the bereavement process.

Method: A meta-synthesis was conducted by database search and article analysis.

Results and Discussion: Eight qualitative style articles were analysed. From these, three categories were derived from the content analysis: I) Relationship between study participants and the deceased; 2) Occupational repercussions of bereavement; and 3) Occupation as a means to an end in the therapy process of the bereaved.

Conclusions: Although the need for studies of the bereavement process and its implications for occupations is urgent, this study points out that occupations can be predictors of understanding the elaboration process through occupational engagement and that they also act as a potential resource to construct meaning about the death of the loved one.

Key words: Occupational therapy, bereavement, grief, mourning, attitude to death

\section{INTRODUCTION}

In this study, bereavement was considered a complex process that occurs through loss, by death, of a significant other. It is a universal, singular, and painful human experience'. Classical authors proposed that bereavement can occur after a significant loss which could be either a serious injury, or being diagnosed with a serious health condition ${ }^{2,3,4}$. Contemporary authors however, state that there are differences between significant losses and death losses ${ }^{5,6,7}$. Bereavement is defined as the objective situation one faces after having lost an important person and a statement of the objective reality of the situation after death ${ }^{5}$. The term grief explains the emotional reactions that occur after a significant loss and relates to the internal, intrapsychic processes ${ }^{5}$ within the person. While grief is present during bereavement, it is the bereavement process which demands the reconstruction of the meaning that can be derived from the loss of a significant person. Therefore, identifying and/or reconstructing meaning helps the individual in the process of bereavement to adapt to a now changed world. This is reflected in the person's social, behavioural, psychological, and physiological health ${ }^{5,6,7}$.

A conceptual model that considers bereavement as an active process of searching for the reconstruction of meaning after losing a significant person, is proposed in literature ${ }^{5}$. It states that finding and/or reconstructing significance during the bereavement process helps the individual adapt to a changed world ${ }^{5}$. The death of a loved one leads to the bereaved individual reviewing their structure of meaning before the loss, and to identify both consistencies and inconsistencies of past structures. Consistency helps to explain the difficult event, while inconsistency leads the bereaved to revise their meaning-making nucleus, perceiving the world in a different way after finding useful meanings ${ }^{5}$.
Occupation is a powerful and intrinsic source of meaning in our lives, in that meaning emerges from occupation, and occupation emerges from meaning ${ }^{8}$. Meaning also comes from the experiences of everyday situations in which a person constructs meanings through a dynamic process of constructing and reconstructing their understandings and explanations of everyday life ${ }^{8}$.

In this study, the concept of occupation as defined by Wilcock was used, which defines occupation as a complex synthesis between doing, being, becoming, belonging, and establishing a complex relationship between health and well-being ${ }^{9,10}$. In this way, it is necessary to understand occupation as a potential source of reconstructing meanings in response to bereavement. Therefore, understanding that bereavement has a direct influence on occupation, and consequently on the health and well-being of those who experience it. The purpose of this study was to review English and Portuguese literature and identify how occupational therapists perceive and/or intervene in the bereavement process.

\section{METHODOLOGY}

The meta-synthesis of literature performed in this study followed the PRISMA model "'. The PRISMA checklist and the Flow Diagram (Figure I on page I3) was used for the preparation of this study. To address our research question "how do occupational therapists understand and/or intervene in the bereavement process?" we reviewed Portuguese and English articles by occupational therapists that focused on the bereavement process.

The databases used were Scopus, CINAHL Database, MEDLINE, PubMed and SciELO; The descriptors used for Portuguese were "Terapia Ocupacional" and "pesar" or "luto" or "atitudes frente a morte," and for English, "occupational therapy" and "grief" or "mourning" or "bereavement." 


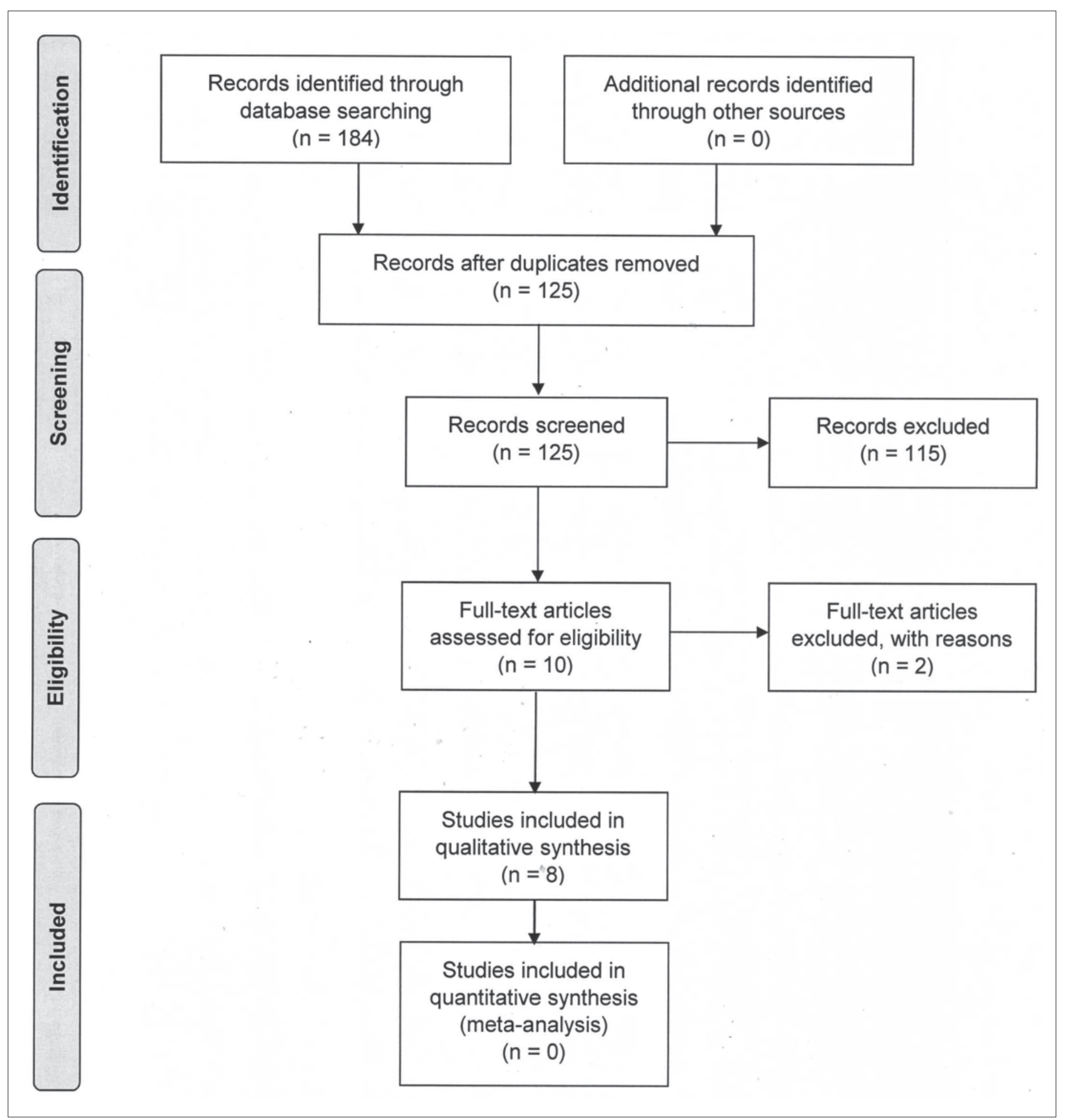

Figure I: PRISMA Flow Diagram

The inclusion criteria were: complete study articles available online, papers about death-related bereavement processes that included at least two keywords, and papers written in either English or Portuguese. No date filtering was performed.

The research was conducted during the period of June 2017 through December 2017 by two independent researchers, with seven days between each search. The articles were read and the results organised, then analysed according to the content analysis criteria as proposed by Bardin ${ }^{12}$ : I) Pre-analysis: operationalising the material by systematically organising the raw data into identified concepts, 2) Exploring of the material: defining the units of analysis through coding elements with the same meanings; and, 3) Treatment of results, inference and interpretation: interpreting the results through inferential analysis.

\section{RESULTS}

The sample

One hundred and eighty four articles were identified from the database search. Of these, 59 duplicate articles were removed. The abstracts of the remaining 125 articles were read to determine whether they met the inclusion criteria, and based on this, II 5 articles were excluded. Ten papers were selected for analysis, however two of these were not available in complete format and were discarded. In total, eight articles were included in this study, with one published in Portuguese and seven in English.

Few articles related directly to occupational therapy intervention for the bereaved and all articles in the review presented qualitative approaches. In all the studies analysed, participants had experienced 
Table I: Articles analysed: Authors, year of publication, journal, adopted methodology, language, and level of evidence

\begin{tabular}{|c|c|c|c|c|c|c|}
\hline Author(s) & Title & $\begin{array}{c}\text { Year of } \\
\text { Publication }\end{array}$ & Journal & Methodologies & Language & $\begin{array}{l}\text { Level of } \\
\text { Evidence }\end{array}$ \\
\hline Hoppes $^{13}$ & $\begin{array}{l}\text { Meanings and Purposes of Caring for a } \\
\text { Family Member: An Auto-ethnography }\end{array}$ & $2005 a$ & $\begin{array}{l}\text { The American Journal } \\
\text { of Occupational } \\
\text { Therapy }\end{array}$ & $\begin{array}{l}\text { Auto- } \\
\text { ethnography }\end{array}$ & English & 5 \\
\hline Hoppes ${ }^{14}$ & $\begin{array}{l}\text { When a Child Dies the World Should Stop } \\
\text { Spinning: An Auto-ethnography Exploring } \\
\text { the Impact of Family Loss on Occupation }\end{array}$ & $2005 b$ & $\begin{array}{l}\text { The American Journal } \\
\text { of Occupational } \\
\text { Therapy }\end{array}$ & $\begin{array}{l}\text { Auto- } \\
\text { ethnography }\end{array}$ & English & 5 \\
\hline $\begin{array}{l}\text { Souza \& } \\
\text { Corrêa }^{15}\end{array}$ & $\begin{array}{l}\text { Compreendo o pesar do luto nas } \\
\text { atividades ocupacionais }\end{array}$ & 2009 & $\begin{array}{l}\text { Revista do Núcleo } \\
\text { de Pesquisas } \\
\text { Fenomenológicas da } \\
\text { UFPA }\end{array}$ & $\begin{array}{l}\text { Experience } \\
\text { report }\end{array}$ & Portuguese & 5 \\
\hline Forhan ${ }^{16}$ & $\begin{array}{l}\text { Doing, Being and Becoming: A Family's } \\
\text { Journey Through Perinatal Loss }\end{array}$ & 2010 & $\begin{array}{l}\text { The American Journal } \\
\text { of Occupational } \\
\text { Therapy }\end{array}$ & $\begin{array}{l}\text { Auto- } \\
\text { ethnography }\end{array}$ & English & 5 \\
\hline $\begin{array}{l}\text { Scaletti \& } \\
\text { Hocking }{ }^{17}\end{array}$ & $\begin{array}{l}\text { Healing through storytelling: An } \\
\text { integrated approach for children } \\
\text { experiencing grief and loss }\end{array}$ & 2010 & $\begin{array}{l}\text { New Zealand Journal } \\
\text { of Occupational } \\
\text { Therapy }\end{array}$ & $\begin{array}{l}\text { Single case } \\
\text { study }\end{array}$ & English & 4 \\
\hline $\begin{array}{l}\text { Hoppes \& } \\
\text { Segal }\end{array}$ & $\begin{array}{l}\text { Reconstructing Meaning Through } \\
\text { Occupation After the Death of a Family } \\
\text { Member: Accommodation, Assimilation, } \\
\text { and Continuing Bonds }\end{array}$ & 2010 & $\begin{array}{l}\text { The American Journal } \\
\text { of Occupational } \\
\text { Therapy }\end{array}$ & Case series & English & 4 \\
\hline $\begin{array}{l}\text { Rosenwax, } \\
\text { Malajczuk \& } \\
\text { Ciccarelli19 }\end{array}$ & $\begin{array}{l}\text { Change in carers' activities after the death } \\
\text { of their partners }\end{array}$ & 2013 & $\begin{array}{l}\text { Supportive Care in } \\
\text { Cancer }\end{array}$ & Case series & English & 4 \\
\hline $\begin{array}{l}\text { Fluegeman, } \\
\text { Schrauben, \& } \\
\text { Cleghorn }^{20}\end{array}$ & $\begin{array}{l}\text { Bereavement support for children: } \\
\text { Effectiveness of Camp Erin from an } \\
\text { occupational therapy perspective }\end{array}$ & 2013 & Bereavement Care & Case series & English & 4 \\
\hline
\end{tabular}

Table II: The titles, purposes, participants, data collection instruments and main results of the analysed articles

\begin{tabular}{|c|c|c|c|c|}
\hline Title & Study Purposes & Participants & $\begin{array}{l}\text { Data collection } \\
\text { instrument }\end{array}$ & Main results \\
\hline $\begin{array}{l}\text { Meanings and Purposes } \\
\text { of Caring for a Family } \\
\text { Member: An Auto- } \\
\text { ethnography } \\
\left.\text { (Hoppes }{ }^{13}\right)\end{array}$ & $\begin{array}{l}\text { Describes the } \\
\text { author's self- } \\
\text { experience as a } \\
\text { caregiver for his } \\
\text { ill father and the } \\
\text { impact grief after } \\
\text { his death had on } \\
\text { his occupations and } \\
\text { family relations }\end{array}$ & The author & $\begin{array}{c}\text { Notes and emotional } \\
\text { memory }\end{array}$ & $\begin{array}{l}\text { Tells the personal story of the author's care } \\
\text { for his sick father, the re-framing of family } \\
\text { relationships, and the need to address existing } \\
\text { problems with loved ones in order to minimize } \\
\text { the impact of grief. }\end{array}$ \\
\hline $\begin{array}{l}\text { When a Child Dies the } \\
\text { World Should Stop } \\
\text { Spinning: An Auto- } \\
\text { ethnography Exploring } \\
\text { the Impact of Family } \\
\text { Loss on Occupation } \\
\quad\left(\text { Hoppes }^{14}\right)\end{array}$ & $\begin{array}{l}\text { Describes self- } \\
\text { perceptions of } \\
\text { the impact of } \\
\text { bereavement has on } \\
\text { family members' and } \\
\text { relatives' occupations }\end{array}$ & The author & $\begin{array}{l}\text { Notes, emotional } \\
\text { recall, discussion and } \\
\text { systematic reflection }\end{array}$ & $\begin{array}{l}\text { Proposes four stages of occupation during } \\
\text { bereavement: I) occupation maintenance: } \\
\text { occupation performance continues while the } \\
\text { severity of the loss is denied; } 2 \text { ) occupational } \\
\text { dissolution: family and daily activities become } \\
\text { devalued and may lose their meaning; } 3 \text { ) } \\
\text { occupational ambivalence: antagonistic feelings } \\
\text { are experienced in relation to occupations that } \\
\text { were previously routine, and 4) restoration } \\
\text { and occupational adaptation: occupations are } \\
\text { restored and adapted to the new condition, and } \\
\text { contemporary plans are resumed while others } \\
\text { are made for the future. }\end{array}$ \\
\hline $\begin{array}{c}\text { Compreendo o pesar } \\
\text { do luto nas atividades } \\
\text { ocupacionais } \\
(\text { Souza \& Corrêa } \\
\text { (S) }^{15}\end{array}$ & $\begin{array}{l}\text { Describes the } \\
\text { experience of } \\
\text { including an } \\
\text { occupational therapist } \\
\text { in a service providing } \\
\text { assistance to } \\
\text { bereaved patients and } \\
\text { the impact grief had } \\
\text { on the occupational } \\
\text { lives of those patients }\end{array}$ & $\begin{array}{l}\text { Patients seeking } \\
\text { support for } \\
\text { bereavement }\end{array}$ & $\begin{array}{l}\text { Interviews and free- } \\
\text { expression activities }\end{array}$ & $\begin{array}{l}\text { The study identified bereavement as a psychic } \\
\text { manifestation that influences the quality } \\
\text { of expression and satisfaction gained from } \\
\text { occupational activities, but also determined } \\
\text { that occupational therapy is still not investing in } \\
\text { understanding the occupational requirements } \\
\text { related to the different possible processes of loss } \\
\text { and grief that are experienced throughout life. }\end{array}$ \\
\hline
\end{tabular}




\begin{tabular}{|c|c|c|c|c|}
\hline Title & Study Purposes & Participants & $\begin{array}{l}\text { Data collection } \\
\text { instrument }\end{array}$ & Main results \\
\hline $\begin{array}{l}\text { Doing, Being and } \\
\text { Becoming: A Family's } \\
\text { Journey Through } \\
\text { Perinatal Loss } \\
\left(\text { Forhan }{ }^{16}\right)\end{array}$ & $\begin{array}{l}\text { Describes the } \\
\text { self-experience of } \\
\text { bereavement after } \\
\text { the perinatal death of } \\
\text { the author's son }\end{array}$ & The author & $\begin{array}{l}\text { Notes, emotional } \\
\text { recall, discussions, } \\
\text { and systematic } \\
\text { reflection }\end{array}$ & $\begin{array}{l}\text { The author describes four phases experienced } \\
\text { by both her and her family after the perinatal } \\
\text { loss of her son: I) starting the journey: the time } \\
\text { prior to delivery until the news of the death of } \\
\text { the child; } 2 \text { ) realizing the loss: the time when } \\
\text { the loss is perceived and the beginning of the } \\
\text { farewells; 3) moving on: initially marked by } \\
\text { intense suffering, the need for social support } \\
\text { and ending with the redefinition of the loss } \\
\text { and establishment of hope; } 4 \text { ) new beginning: } \\
\text { marked by the balance between the need to } \\
\text { recognize the existence of the child and its } \\
\text { absence. }\end{array}$ \\
\hline $\begin{array}{l}\text { Healing through story } \\
\text { telling: An integrated } \\
\text { approach for children } \\
\text { experiencing grief and } \\
\text { loss } \\
\text { (Scaletti \& Hocking }{ }^{17} \text { ) }\end{array}$ & $\begin{array}{l}\text { Describes the } \\
\text { integrated use of the } \\
\text { sand-tray therapy, } \\
\text { peer groups, and the } \\
\text { creation of history } \\
\text { books to help a } \\
\text { bereaved child }\end{array}$ & $\begin{array}{l}\text { An eight-year- } \\
\text { old child who } \\
\text { lost their father } \\
\text { in an automobile } \\
\text { accident }\end{array}$ & $\begin{array}{l}\text { Creating a story using } \\
\text { a sand tray }\end{array}$ & $\begin{array}{l}\text { This study reports that the creation of a story } \\
\text { in a picture book allows children to repeatedly } \\
\text { tell the story to the public, regardless of } \\
\text { whether it is real or imaginary, and this makes } \\
\text { it possible to integrate the feelings that might } \\
\text { arise. Thus, behavioural manifestations of grief } \\
\text { and anger decrease as the child develops higher } \\
\text { occupational competence, and this is observed } \\
\text { at home, at school, and in interactions. }\end{array}$ \\
\hline $\begin{array}{l}\text { Reconstructing Meaning } \\
\text { Through Occupation } \\
\text { After the Death of } \\
\text { a Family Member: } \\
\text { Accommodation, } \\
\text { Assimilation, and } \\
\text { Continuing Bonds } \\
\text { (Hoppes \& Segal }^{18} \text { ) }\end{array}$ & $\begin{array}{l}\text { Identifying, describing } \\
\text { and analysing } \\
\text { the occupational } \\
\text { responses of } \\
\text { bereaved }\end{array}$ & $\begin{array}{l}\text { Thirty-one } \\
\text { people with } \\
\text { grief-related } \\
\text { stories } \\
\text { concerning to } \\
\text { the death of a } \\
\text { family member: } \\
\text { a parent (I8), } \\
\text { child (5), } \\
\text { Grandparent } \\
\text { (4), spouse }(2) \text {, } \\
\text { brother (I), } \\
\text { niece (I) }\end{array}$ & $\begin{array}{l}\text { Semi-structured } \\
\text { interview }\end{array}$ & $\begin{array}{l}\text { This study identifies three distinct occupational } \\
\text { processes that are fundamental for the } \\
\text { reconstruction of meaning in life after the } \\
\text { loss of a family member: I) Occupational } \\
\text { Accommodation: which refers to the } \\
\text { transformation of occupational standards } \\
\text { in response to the change in reality; 2) } \\
\text { Occupational Assimilation: which refers to } \\
\text { adaptations of occupations as a method of } \\
\text { coping with loss; and 3) Continuing Bonds: } \\
\text { which refers to the performance of occupations } \\
\text { in order to maintain bonds with the deceased. } \\
\text { The investigated occupation areas were: work, } \\
\text { leisure, and social participation. }\end{array}$ \\
\hline $\begin{array}{c}\text { Change in carers' } \\
\text { activities after the death } \\
\text { of their partners } \\
\text { (Rosenwax, Malajczuk \& } \\
\text { Ciccarelli }{ }^{19} \text { ) }\end{array}$ & $\begin{array}{l}\text { Describes the } \\
\text { occupational } \\
\text { changes before and } \\
\text { after caregiving for } \\
\text { wives of patients in } \\
\text { palliative care and the } \\
\text { factors that helped } \\
\text { them resume their } \\
\text { activities two years } \\
\text { after the death of } \\
\text { their partners. }\end{array}$ & $\begin{array}{l}\text { Forty women } \\
\text { who acted as } \\
\text { caregivers for } \\
\text { a partner who } \\
\text { died of cancer } \\
\text { two years } \\
\text { previously }\end{array}$ & $\begin{array}{l}\text { I) Activity Card } \\
\text { Sort-Australia (ACS- } \\
\text { Australia) } \\
\text { 2) SF-36 Health } \\
\text { Survey v2 (SF-36v2) } \\
\text { 3) Multidimensional } \\
\text { Scale of Perceived } \\
\text { Social Support } \\
\text { (MSPSS) }\end{array}$ & $\begin{array}{l}\text { By comparing the pre- and post-care periods, } \\
\text { this study indicates that at two years after } \\
\text { the death of the partner they were caring for, } \\
\text { the caregivers had become more engaged in } \\
\text { domestic activities; however, there was also a } \\
\text { concurrent decline in engagement in social and } \\
\text { leisure activities }\end{array}$ \\
\hline $\begin{array}{l}\text { Bereavement } \\
\text { support for children: } \\
\text { Effectiveness of } \\
\text { Camp Erin from an } \\
\text { occupational therapy } \\
\text { perspective } \\
\text { (Fluegeman, Schrauben, } \\
\text { \& Cleghorn }{ }^{20} \text { ) }\end{array}$ & $\begin{array}{l}\text { Identifying whether } \\
\text { the activities } \\
\text { conducted, and the } \\
\text { relationships created } \\
\text { at Camp Erin had } \\
\text { any impact on the } \\
\text { grieving process and } \\
\text { what the possible } \\
\text { contributions of } \\
\text { occupational therapy } \\
\text { could be in such } \\
\text { assistance programs }\end{array}$ & $\begin{array}{l}\text { Ten bereaved } \\
\text { children and four } \\
\text { counsellors }\end{array}$ & $\begin{array}{l}\text { Focus groups with } \\
\text { bereaved children } \\
\text { and semi-structured } \\
\text { interviews with } \\
\text { counsellors }\end{array}$ & $\begin{array}{l}\text { This study highlights the theory that the activities } \\
\text { offered at Camp Erin, and the relationships } \\
\text { created there, are effective for supporting } \\
\text { children who are experiencing the grieving } \\
\text { process. This study identified that children } \\
\text { require assistance to transpose the skills learned } \\
\text { at the camp to everyday life at home, at school, } \\
\text { and in the community. }\end{array}$ \\
\hline
\end{tabular}

the death of a family member. Table I (page 14) shows the detail on the eight articles selected for analysis namely author(s), title, year of publication, journal, methodology, language and level of evidence. Three of the articles were auto-ethnographies and three were case series, one was a case study and one was a personal experience report. Table II (pages 14 and I5) summarises the purpose, participants, data collection instruments used, and main findings of each of the eight selected articles.

\section{Main findings of the studies included in this analysis}

Hoppes $^{13}$ and Forhan ${ }^{16}$ (from their own experience of the death of a loved one) proposed theoretical models to help understand 
how the process of bereavement influenced their own occupations and the occupations of family members. Both included descriptions of interpersonal interactions between family members during the bereavement process. Hoppes and Segal ${ }^{18}$ propose a theoretical model based on the contemporary concept of the reconstruction of meanings in response to bereavement, from the experience of people who have lost a loved one.

In another paper by Hoppes ${ }^{14}$, his own experience of caring for and witnessing the passing of a sick father provided him with a potentially therapeutic learning situation, as, through the creation of new meanings to the relationship with his dad and reconstruction of meanings for the continuation of these bonds after death, aided him in his own bereavement process.

Souza and Corrêa ${ }^{15}$ and Scaletti and Hocking ${ }^{17}$ found occupational changes in their participants and reported the use of occupations as a powerful source of expression of grief. The Souza and Corrêa ${ }^{15}$ study used a workshop for free expression and the Scaletti and Hocking ${ }^{17}$ study used a sand-tray through which to express grief.

Rosenwax, Malajczuk, and Ciccarelli ${ }^{19}$ found that for wives who cared for partners receiving palliative care, there was a decrease in their social and leisure activities, with increased participation in domestic activities up to two years after bereavement. Finally, the study by Fluegeman, Schrauben, and Cleghorn ${ }^{20}$ showed that bereaved children and adolescents reduced their social participation, showed a tendency towards social isolation, and reported difficulties expressing their feelings.

\section{DISCUSSION}

Bereavement receives little attention in occupational therapy literature $^{16,18}$. However, even less attention is given to publications in the Portuguese language. Adopting a qualitative perspective towards bereavement research provides an alternative paradigm to the current research methodology employed in the studies analysed. By using a wide range of techniques, including data collection, analysis, and interpretation, qualitative analysis has the potential to add depth to evaluating the bereavement process ${ }^{2}$. Consequently, auto-ethnographic studies, studies of single cases or a series of cases are made relevant through the personal involvement of the researcher. The narrative of their thoughts and opinions includes all aspects of their emotional experience, which reveals hidden details of their private lives ${ }^{22}$. In addition, the accounts revealed subtle nuances and supports the need for a closer examination by the person experiencing the phenomenon being studied ${ }^{23}$. Our study agrees with the statement made by Hoppes and Segal ${ }^{18}$ who report that contemporary understandings about grief, continuing bonds, reconstruction of meaning, and adaptation are important to the practice of occupational therapists. However, if we are to explain to other disciplines what we have to offer, and if we are to shape effective, occupation-based therapies for people who have experienced significant losses, we need evidence, illustrations, and theory-specific to occupation ${ }^{18}$. The studies we analysed facilitated the understanding of both the therapeutic use of occupation with the bereaved, and understanding the impact to their occupational performance. However, we need to go further by building a specific methodological framework for occupational therapy in order to understand and intervene with the bereavement process.

Further insights into the impact of bereavement on occupations were gained as a result of the content analysis, from which the following three categories were identified:

\section{Category I: The relationship between study participants and the deceased}

The impact of death creates a systemic demand on the family, at both an emotional and relational level. This crisis stems from the need of the bereaved to resume their own roles, whilst having to share the bereavement experience of other family members. Their own bereavement is therefore aggravated by the grief of other members of the family ${ }^{24}$. Bereavement causes transformation and an abrupt change in a "me/you" relationship; thus, the sense of a lost relationship is a key element of understanding this experience ${ }^{25}$.

When there is an interruption in a person's occupation with the deceased, changes in lifestyle arise, causing abandonment of roles or an inability to perform activities with and for the loved one who died. The bereaved consequently question what they will do without the presence of the loved one, and consequently, grieve over being forced to forgo activities that were once shared. In this way, they are required to renounce old and enjoyable shared activities, rebuild their world, and adapt to other activities that have replaced the old ones. This can be achieved by entering a new situation, adopting another way of performing such activities, or accepting another, new reality that lacks the physical presence of the loved one ${ }^{15,26}$.

\section{Category 2: The repercussions of bereavement on occupations}

When a loved one dies, the concepts held about the world (which were validated by the other person's existence), are suddenly lost. Habits of thought, built over many years will need to be revised and modified and the worldview of the bereaved will need to change ${ }^{2}$. Parkes $^{2}$ states that the bereaved person goes through a Psychosocial Transition, understood as the process in which they will assume a new identity as they assume a new world model, defined by new roles and a new repertoire of solutions to the problems of the "new" life. Bereavement tends to produce changes in everyday life and in the occupational performance of the bereaved, since the death of a loved one can trigger a singular and personal movement towards the reinterpretation of life itself; the loss therefore disrupts the coherence of the individual's self-narrative ${ }^{5}$.

The death of a loved one interferes with occupations that were previously performed for, or with, the person who died, changing the synthesis between doing, being, becoming and belonging. The findings of the studies we analysed confirm this premise, and continued research leading to improved understanding is of value to guiding occupational therapists in the care of the bereaved. Occupational therapists should be taught how to recognise a person's disconnection from their occupations during the bereavement process ${ }^{15}$. Hoppes ${ }^{13}$ claims that as occupational therapists, we hold a powerful compass that can assist family members in a search for meaning after loss.

For this author, occupation can serve as a compass for the construction of ways to understand bereavement and the construction of meanings in response to bereavement. The understanding of how occupations can be terribly confusing after the loss of a loved one guides our vision as occupational therapists and assists us to guide the bereaved through this process like no other professional can ${ }^{13}$.

Hasselkus ${ }^{8}$ helps us consider the implications that bereavement brings to occupational meaning. For this author, occupation is a strong enabler to knowing one's self, and to know one's self is to know one's being. A way that my self becomes known to me, and one way that my self is expressed in the world, is through occupation. In the bereavement process, the self-identity of the bereaved becomes inconsistent against the reality of loss ${ }^{2,5,25}$.

Becoming holds the notion of potential and growth, of transformation and self-actualisation 9.10 . Many times, the bereaved see themselves without future prospects and they question their potential, which increases their grief over the loss ${ }^{24,25,26}$.

The uniqueness of the bereavement process reinforces the need for a client-centred therapeutic process, and the occupational therapist must identify the best form of interaction with the bereaved, beginning the therapeutic process by reflecting about what changes must be made to give back to the client - through therapy - their notion of potential ${ }^{8}$.

Belonging is recognised by a sense of connection with another person, places, cultures, communities and times ${ }^{10}$. Belonging is a place capable of providing physical and emotional security, provide both private and community space that meets social needs and helps form a group identity ${ }^{27}$. The sense of belonging undergoes significant modifications when the conspiracy of silence is installed. 
The bereaved believe that silence about the death of a loved one modifies their sense of connection with that person and places ${ }^{28}$. This happens because the bereaved feel the need to talk about the deceased, but they do not find space or people available to do so, reinforcing a sense of not belonging and increasing social isolation ${ }^{25,26}$.

The bereaved person temporarily loses the willingness to listen, but has an urgent need to speak. This brings significant changes to their ability to communicate, which may reinforce the feeling of loneliness and as a result, the intensity of the bereavement depends on the human support that the bereaved receives ${ }^{29}$. Occupational therapists can offer support for the bereaved and help them search for places in the community that can offer support during the bereavement process such as mutual aid groups for different kinds of bereavement that can be accessed to increase the bereaved person's sense of belonging.

\section{Occupation as a means-to-an-end in the therapy process of the bereaved}

Participation in occupations is considered the final result of an intervention, and professionals use occupations during the intervention process as a means-to-an-end ${ }^{30}$.

The use of occupations was reported as a means of understanding and intervening during bereavement ${ }^{15,17,20}$. The therapeutic use of artistic approaches such as music, creative writing, and visual arts, along with other practices and multi-mode performances, are potential resources for the construction of meanings related to grief and bereavement ${ }^{31,32}$.

Hasselkus ${ }^{8}$ believes that one way to know the meaning of experience occurring in a person's everyday life is the narrative therapy of meaning, since by telling a story, one relates his or her unique interpretation of an experience. Narrative as sources of meaning thus offer a way for us to frame the practice of occupational therapy.

Understanding that the bereavement process comes from the reconstruction of meanings, occupational therapists can use occupations to care for bereaved people, because the occupation is a powerful source of meaning. Narrative as a construction of meaning can offer us one way to understand the changes of meaning of occupations and help the bereaved to reconstruct their occupational performance. The narrative organises the discourse and the lived experience, creating stories that temporarily give meaning to the events in a social context, according to personal religious and cultural beliefs. Narrative therapies have gained space as an effective type of grief therapy because it offers strategies for the bereaved to elaborate about their bereavement experience ${ }^{33}$.

In other studies, ${ }^{13,14,16,18,19,20}$, occupation is used as an end, because studies were concerned with the performance of occupations in the everyday life. Occupational therapists use their knowledge of the transactional relationship within the person, his or her engagement in valued occupations, and its context to design occupation-based intervention. Therefore, we are concerned with the end result of participation ${ }^{30}$.

It is necessary to understand that a person has an individualised occupational pathway toward recovery after the death of a family member. For some people, returning to their routine will facilitate recovery; for others, new occupations are necessary and therapeutic. In helping a bereaved person, it is important not to focus on a particular strategy or on the motives for engaging in a specific occupation; rather, it is crucial to understand and accept individual responses to facilitate the bereavement process ${ }^{18}$

The studies we analysed have shown transformations in occupational performance, ranging from the inclusion of new occupations, the adaptation of previously performed occupations, the preference of certain occupations, and the discarding of others.

For Hasselkus ${ }^{8}$, it is by doing, that meaning is realised in our lives.

\section{CONCLUSIONS}

By understanding the individual nature of bereavement, that it is singular, culturally contextualised, and with no room for generalisation, we believe in conducting additional studies and developing enhanced theories, approaches, and practices to connect the occupational therapist with the bereaved.

This study identified that bereavement affects the occupational performance of the bereaved who has lost a loved one and that occupation can be used for the construction of new meanings in response to bereavement, helping minimise occupational impact in the everyday life of bereaved.

Occupational therapists can use the therapeutic power of occupations, either as a means or as an end, to assist the bereaved in this process.

Finally, we reiterate that further studies are necessary to provide evidence for the theoretical and practical construction of occupational therapy for these persons.

\section{REFERENCES}

I. Barreto P, Yi P, Soler C. Predictores de duelo complicado. Psicooncologia. 2008; 5 (2-3): 383-400.

2. Parkes CM. Amor e perda: as raízes do luto e suas complicações. São Paulo: Summus, 2009.

3. Worden JW. Terapia do Luto: um manual para o profissional de saúde mental. Porto Alegre: Ed. Artes Médicas, 1998.

4. Freud S. Luto e Melancolia. In: Edição Standard Brasileira das Obras Psicológicas Completas de Sigmund Freud. Vol. XIV. Freud S., Rio de Janeiro: Imago; 1996: 245-263.

5. Gillies J, Neimeyer R. Loss, grief, and the search for significance: Toward a model of meaning reconstruction in bereavement. Journal of Constructivist Psychology. 2006; I9(I): 3I-65.

6. Stroebe MS, Hansson RO, Schut H, et al. Handbook of Bereavement Research and Practice: Advances in Theory and Intervention. Washington, DC: American Psychological Association, 2008.

7. Stroebe M, Schut $\mathrm{H}$. The dual process model of bereavement: Rationale and description. Death Studies. 1999; 23(3): 197-224

8. Hasselkus BR. Meaning of Everyday Occupation. Thorofare: Slack Incorporated; 20II.

9. Wilcock A. Reflections on doing, being and becoming. Aust Occup Ther J. 1999; 46: I-II.

10. Hitch D, Pépin G, Stagnitti K. In the Footsteps of Wilcock, Part One: The Evolution of Doing, Being, Becoming, and Belonging. Occupational Therapy In Health Care, 20I4; 28(3): 23I-246. DO I: 10.3109/07380577.20I4.898||4

II. Moher D, Liberati A, Tetzlaff J, Altman DG, \& The PRISMA Group. Preferred reporting items for systematic reviews and meta-analyses: The PRISMA statement. Annals of Internal Medicine. 2009; I I I (4): 264-269. DOI: |0.7326/0003-48|9-|5|-4-200908|80-00|35

12. Bardin L. Análise de conteúdo. São Paulo: Edições 70; 2010.

13. Hoppes $S$. When a child dies the world should stop spinning: An autoethnography exploring the impact of family loss on occupation. American Journal of Occupational Therapy. 2005; 59(I), 78-87. DOI: 10.50I4/ajot.59.1.78

I4. Hoppes S, Segal R. Reconstructing meaning through occupation after the death of a family member: Accommodation, assimilation, and continuing bonds. American Journal of Occupational Therapy. 20I0; 64(I), I33-14I. DOI: I0.50I4/ajot.64.1.I33

I5. Souza AM, Corrêa VAC. Compreendendo o pesar do luto nas atividades ocupacionais. Revista do NUFEN. 2009; I (2), I3I- I 48. $<$ http://pepsic.bvsalud.org/scielo.php?script $=$ sci_arttext\&pi$\mathrm{d}=\mathrm{S} 2 \mathrm{I} / \mathrm{75}$

I6. Forhan M. (2010). Doing, being, and becoming: A family's journey through perinatal loss. American Journal of Occupational Therapy. 20I0; 64(I), |42-I5I. DOI: I0.50I4/ajot.64.I.I42

17. Scaletti R, Hocking C. Healing through story telling: An integrated approach for children experiencing grief and loss. New Zealand Journal of Occupational Therapy. 2010; 57(2), 66-7I.

18. Hoppes S. Meanings and purposes of caring for a family member: an autoethnography. American Journal of Occupational Therapy. 2005; 59(3), 262-272. DOI: |0.50|4/ajot.59.3.262259|2009000200009> (9 Jun 2017)

19. Rosenwax L, Malajczuk S, Ciccarelli, M. Change in carers' activities after the death of their partners. Supportive Care in Cancer. 2014; 22(3), 619-626. DOI: 10.1007/s00520-0|3-2014-I

20. Fluegeman JE, Schrauben AR, Cleghorn SM. Bereavement support for children: Effectiveness of Camp Erin from an occupational 
therapy perspective. Bereavement Care. 20I3; 32(2), 74-8I. DOI: I0.1080/0268262I.20I3.8I2820

21. Stroebe M, Stroebe W, Schut H. Bereavement research: Methodological issues and ethical concerns. Palliative Medicine. 2003; 17(3), 235-240. DOI: 10.1191/0269216303pm768rr

22. Ellis C, Bochner AP. Autoethnography, personal narrative, reflexivity: researcher as subject. In: Handbook of qualitative research. Denzin NK, Lincoln YS, editors. London: Sage Publications; 2000; 733-778.

23. Yin RK. Estudo de caso: planejamento e métodos. Porto Alegre: Bookman; 2015.

24. Bromberg MHPF. Luto: a morte do outro em si. In: Vida e morte: laços da existência. Bromberg MHPF, Kovács MJ, Carvalho MMMJ, Carvalho VA, editors. São Paulo: Casa do Psicólogo, 1996; 99-I2I

25. Freitas JL. Luto e fenomenologia: Uma proposta compreensiva. Revista da Abordagem Gestáltica - Phenomenological Studies. 2013; 19(I), 97-105.

26. Dahdah DF, Rego F, Bombarda, TB, et al. Daily Life and Maternal Mourning: A Pilot Study. Death Studies, 2018. DOI: 10.1080/0748II87.2018.1458762

27. Rebeiro KL, Day DG, Semeniuk B, O'Brien MC, Wilson B. Northern Initiative for Social Action: An Occupation-Based Mental Health Program. Am J Occup Therpy, 200I; 55(5): 493-500. DOI: I0.50I4/ ajot.55.5.493.

28. Kovács MJ. Educação para a morte. Psicologia: Ciência e Profissão, 2005; 25(3): 484-497. DOI: I0.I590/S I I 4-989320050003000I 2

29. Rebelo JE. Defilhar: Como Viver a Perda de um Filho. Alfragide: Casa das Letras, 2013.

30. American Occupational Therapy Association. Occupational therapy practice framework: Domain and process (3rd ed.). American Journal of Occupational Therapy. 20I 4; 68 (Suppl. I): SI-S48. DOI: I0.50|4/ajot.20|4.682006

31. Neimeyer RA, Thompson BE. Meaning making and the art of grief therapy. In: Grief and the expressive arts: Practices for creating meaning. Thompson BE, Neimeyer RA, editors. New York: Routledge; 2014: 3-13.

32. Neimeyer RA. Meaning reconstruction and the experience of loss. Washington DC: American Psychological Association; 200I: 26I-292.

33. Neimeyer RA. Narrative strategies in grief therapy. Journal of Constructivist Psychology, 1999; 12 (I): 65-85. DOI: I0.1080/107205399266226.

\section{Corresponding Author}

\section{Daniel Ferreira Dahdah}

Email: daniel_dahdah@hotmail.com 